\title{
INTELLECTUAL PROPERTY, FOREIGN DIRECT INVESTMENT AND THE CHINA EXCEPTION
}

\author{
Peter K. Yu ${ }^{*}$
}

\section{INTRODUCTION}

Policymakers in both the developed and less developed worlds have increasingly considered intellectual property protection as a major means to attract foreign direct investment (Yu, 2007, pp. 892-901). However, stronger intellectual property protection is not always needed to attract such investment. In the case of China, foreign investors were not attracted by the strong intellectual property protection the country offers. Rather, they entered the Chinese market because of the drastically lower production costs, the country's enormous market, its inefficient economic system and the preferential treatment of foreign investors. Thus, some commentators consider China a paradigmatic case for showing how rapid economic development can take place despite limited intellectual property protection (Abbott, 2005, p. 81; Chow, 2007, p. 199).

Although the piracy and counterfeiting problems in China have been widely reported in the media in the past decade, the protection of intellectual property rights was a rather recent institution in the country. Modern copyright, patent and trademark laws were not introduced until after China reopened its market to foreign trade in the late 1970s (Yu, 2000, pp. 136-141). Since then, the country revamped its intellectual property system in response to U.S. pressure in the late 1980s and early 1990s and did so again in preparation for its accession to the World Trade Organization (WTO) (Yu, 2000, pp. 141-151; Yu, 2006, pp. 906-923). At present, China is a proud member of many multilateral intellectual property agreements, including the Berne Convention, Geneva Convention, Paris Convention, the Patent Cooperation Treaty and UPOV (International Union for the Protection of New Varieties of Plants).

Notwithstanding these developments, the enforcement of intellectual property rights in China remains inadequate. Every year, U.S. industries are estimated to have lost billions of dollars due to piracy and counterfeiting in the country. As the International Intellectual Property Alliance stated in its recent Special 301 Report, copyright piracy in China resulted in $\$ 2.2$ billion of U.S. trade losses in 2006 alone (International Intellectual Property Alliance, 2007, p. 96). Of particular concern is the considerable quantity of the infringing products that have been exported to other foreign markets. To protect its industries, the United States has recently requested consultations with China over its failure to comply with the Agreement on Trade-Related Aspects of Intellectual Property Rights (TRIPS Agreement) concerning protection and enforcement of intellectual property rights. ${ }^{1}$

\footnotetext{
* Copyright (C) 2007 Peter K. Yu. This Chapter was abridged and adapted from Peter K. Yu (2007), 'Intellectual Property, Economic Development, and the China Puzzle', in Daniel J. Gervais (ed.), Intellectual Property, Trade and Development: Strategies to Optimize Economic Development in a TRIPS Plus Era, Oxford: Oxford University Press, pp. 169-216.
} 
This chapter examines the causal relationship between the strength of intellectual property protection and the amount of foreign direct investment (FDI) - 'the act of establishing or acquiring a foreign subsidiary over which the investing firm has substantial management control' (Maskus, 1998, p. 119). The chapter begins with a theoretical discussion of the relationship between these two variables and challenges the claim that China is the proverbial exception to this relationship. The chapter argues instead that China illustrates rather well the theoretical and empirical ambiguity of the conventional linkage between intellectual property protection and FDI as well as the complex interplay of the different location advantages that affect private investment decisions.

The chapter then examines why China expanded its intellectual property protection even though such expansion was unnecessary for attracting FDI. Tracing the growing protection to both external pressure and internal push, the chapter contends that intellectual property reforms were introduced because they promoted economic development in certain parts of the country and resulted in the creation of local stakeholders who benefited from and lobbied for stronger protection.

\section{INTELLECTUAL PROPERTY AND FOREIGN DIRECT INVESTMENT}

Conventional wisdom holds that strong intellectual property protection is needed to attract foreign investment in less developed countries, because firms are reluctant to invest in a foreign country unless they are assured of protection of their intellectual assets and financial investment. However, recent empirical research questions this conventional wisdom. As Carsten Fink, Keith Maskus, Carlos Primo Braga and other economists have shown, intellectual property protection is more likely to attract FDI if two additional conditions are met (Maskus, 1998, pp. 130-131; Maskus, 2000; Primo Braga and Fink, 1998 , p. 164). First, the country needs to have a strong capacity to imitate foreign products and technologies. If local competitors are unable to copy these products and technologies, the business interests of foreign firms are unlikely to be threatened, and intellectual property protection will be unnecessary. Second, the country needs to have a sufficiently large market to enable foreign firms to capture economies of scale or scope (Heald, 2003, p. 266). In a country that lacks such a market, foreign firms are unlikely to find it advantageous to move their productions abroad.

Even if these two conditions are met, policy makers still have to question what form of protection needs to be strengthened in order to promote economic development. Paul Heald and Keith Maskus each suggested that firms that seek to establish manufacturing or research-and-development plants are unlikely to require more protection than what is needed to ensure the non-disclosure of technologies brought in by foreign firms (Heald, 2003, pp. 258-260; Maskus, 1998, pp. 119-128). While these firms need trade secrets and contractual protection, firms seeking to establish markets for finished products need copyright, patent and trademark protection instead. Thus, it is important to separate investment decisions that seek to relocate manufacturing or research-and-development facilities from those that seek to market finished products. 
While strong intellectual property protection is a main concern for marketing decisions, a decision to relocate manufacturing facilities is likely to be determined by such 'location advantages' as 'market size and growth, local demand patterns, transport costs and distance from markets, low wage costs in relation to labor productivity, abundant natural resources, and trade protection that could encourage "tariff-jumping" investments' (Maskus, 1998, p. 123). Likewise, a decision to relocate research-anddevelopment facilities is likely to be affected by 'the level of education and training of the local workforce, the condition of its financial sector, the health of its legal system, and the transparency of governmental procedures' (Heald, 2003, p. 259).

To make things more complicated, firms can resort to many different investment strategies, and FDI is only one of them. Using John Dunning's ownership-locationinternalization framework (Dunning, 1981, pp. 110-112), economists have shown that, even in the presence of favorable location advantages, firms still need to decide whether they want to serve foreign markets through FDI, export finished products to the less developed market, conduct arm's-length technology licensing, set up joint ventures with local manufacturers or distributors or ignore the foreign market entirely (Maskus, 1998, 130). As Carlos Primo Braga and Carsten Fink explained:

In order for firms to invest abroad, two further conditions must be met. First, the foreign country must offer location advantages that make it more profitable to locate business abroad. Location advantages are usually associated with factors such as high transportation costs and tariffs, low input prices, access to distribution networks, and local regulatory environments. Second, it must be more profitable for firms to internalize production rather than to sell or license their intellectual assets to independent local firms in the foreign country. Internalization advantages take the form of avoiding transaction costs with potential licensees, controlling inputs, and protecting quality (Primo Braga and Fink, 1998, p. 170).

While the strength or weakness of intellectual property protection will 'influence a firm's decision to internalize or externalize its intellectual assets', it is only one of the many location advantages that influence such a decision (Ibid, p. 171). As Keith Maskus put it in the FDI context, 'IPRs are an important component of the general regulatory system, including taxation, investment regulations, production incentives, trade policies, and competition rules. The joint implementation of an overall pro-competitive business environment matters most for FDI' (Maskus, 1998, p. 129).

Paradoxically, the strengthening of intellectual property protection may encourage firms to conduct more arm's-length technology licensing, which in turn will result in a reduction of FDI. As Primo Braga and Fink explained, intellectual property protection can affect foreign investment in two negative ways: 'First, stronger IPR protection provides title holders with increased market power and could, at least theoretically, cause firms to actually divest and reduce their service to foreign countries. Second, higher levels of protection may cause [transnational corporations] to switch their preferred mode of delivery from foreign production to licensing' (Primo Braga and Fink, 1998, p. 172). Whether a firm will choose to license will depend on transaction costs - in particular, the robustness of the local regulatory regimes, the existence of a contracting culture and experience and the availability of information needed to evaluate the transactions. In 
places where there is limited intellectual property protection, the firm's need to internalize foreign production to maintain direct control over their proprietary assets may also affect licensing decisions (Ibid). If the firm chooses to externalize its production through, say, licensing, stronger intellectual property protection arguably would have the 'cancel out' effect of reducing FDI.

Finally, most firms do not need to make the difficult decision between relocating their entire facilities and not relocating at all. They can simply decide which type of operations they want to relocate abroad and whether they want to combine FDI with other investment strategies, such as export, licensing or establishment of joint ventures. Even if they choose to relocate abroad, they can still decide 'where to invest and in what kind of facilities, whether to purchase existing operations or construct new plants (so-called "greenfield investments"), which production techniques to pursue, and how large an equity position to take with potential local partners' (Maskus, 1998, p. 113).

Economists generally distinguish between 'horizontal FDI' and 'vertical FDI'. While the former refers to the investment made when 'firms establish plants abroad to produce the same or similar goods for local or regional markets', the latter 'occurs if plants in different countries produce outputs that serve as inputs in other plants' (Primo Braga and Fink, 1998, pp. 172-173). Although intellectual property protection affects both horizontal and vertical FDI, the amount and composition of FDI vary according to the impact of such protection on the particular production process.

For example, Edwin Mansfield observed in his influential study for the World Bank that,

[w]hile U.S. firms may be quite willing to invest considerable amounts in sales and distribution outlets and in rudimentary production and assembly facilities in countries with weak protection, their investments in $\mathrm{R}$ and $\mathrm{D}$ facilities or in facilities to manufacture components or complete products may be more likely to go to countries with stronger protection systems' (Mansfield, 1994, p. 17).

Because '[v]ertical FDI is more prevalent among [multinational enterprises] that invest in developing (low-wage) economies, while horizontal FDI tends to characterize the investment decisions of MNEs operating across borders within the industrialized, developed nations', the amount and proportion of each type of investment may fluctuate with the country's economic development (Maskus, 1998, p. 120). As the country becomes more developed economically, the amount of horizontal FDI may increase while that of vertical FDI may decrease.

In sum, countries that lack a strong imitative capacity and a sufficiently large market are unlikely to benefit from stronger intellectual property protection. However, even if countries meet these two prerequisites, stronger intellectual property protection may be unnecessary for attracting FDI. It depends on the complex interactions between the different location advantages, especially when some of these advantages are significant enough to compensate for the lack or ineffectiveness of strong intellectual property protection. Thus, the relationship between the strength of intellectual property protection and FDI remains theoretically ambiguous. 


\section{THE CHINA EXCEPTION}

Commentators often consider China as an exception to the causal relationship between the strength of intellectual property protection and the amount of FDI attracted to the country. However, China is not the exception they suggested. Rather, it illustrates well the ambiguity of this relationship and the complex interplay of the different location advantages that can affect private investment decisions.

To begin with, China has met the two prerequisites needed for a country to benefit from stronger intellectual property protection. Since the reopening of its market to foreign trade in the late 1970s, China has developed a strong imitative capacity. In fact, such capacity explains China's ability to produce a large amount of pirated and counterfeit products. Moreover, China has seen tremendous economic growth in the past two decades (Bergsten, Gill, Lardy and Mitchell, 2006, p. 18; Yu, Chang, Cohen, Economy, Hom and Li, 2003, p. 3). Today, China boasts a healthy market of hundreds of millions of customers, even though it has yet to offer one billion customers as some would hope. It also has become one of the world's largest surplus countries, possessing one of the most sizeable foreign exchange reserves in the world (Bergsten, Gill, Lardy and Mitchell, 2006, p. 4).

Nevertheless, intellectual property protection in the country remains inadequate and ineffective, and it is unlikely that foreign firms were attracted to China because of its intellectual property system. Instead, firms often relocate to China to take advantage of the lower production costs and the emerging market. To many of these firms, the lower costs and the promise of an enormous market would easily make up for the losses incurred by ineffective intellectual property protection (Tackaberry, 1998, p. 26). While these firms certainly welcome greater intellectual property reforms, they do not find stronger protection a prerequisite for obtaining profits in the first place. In fact, many major Western firms-like Coca-Cola, Kodak, Motorola, Procter \& Gamble and Siemens - have already been enjoying substantial profits for years despite serious piracy and counterfeiting problems (Sun, 2004, pp. 4-5). Thus, instead of seeing strong intellectual property protection as the necessary precursor to profitability, they see it more as a means to 'increas[e their] already acceptable profit ratios' (Ibid, p. 5).

Other firms, especially those that are new to China or are unfamiliar with the local conditions, have been less successful. Nevertheless, they consider the emerging Chinese market too large to ignore. While some consider the losses unavoidable as they build up their market share and improve their position in this emerging market, others write off their piracy-related losses as promotional expenses. The latter approach easily reminds one of the remark Microsoft's founder Bill Gates made a few years ago. When questioned about the widespread piracy of Microsoft software in China, Gates observed: 'Although about three million computers get sold every year in China, people don't pay for the software. Someday they will, though. And as long as they're going to steal it, we want them to steal ours. They'll get sort of addicted, and then we'll somehow figure out how to collect sometime in the next decade' (Schlender, Buffett and Gates, 1998). 
Recent research, however, has revealed a more complicated picture concerning FDI in China. The amount of FDI in a country does not depend only on 'pull' factors, but also on 'push' factors, such as those that have made the country unappealing for local production. As Huang Yasheng pointed out in his provocative book, Selling China, the inefficiencies of the Chinese economic system and the country's preferential treatment of foreign investors have led to a large amount of FDI in the country (Huang, 2005). Because commentators tend to focus on the attractions of the Chinese market, they often ignore how ' $[\mathrm{t}] \mathrm{he}$ poor profitability of the state sector, the credit constraints on the part of Chinese private firms, the insecurity of private property rights, and the weaknesses of domestic firms have all driven up China's demand for FDI' (Ibid, p. 81).

To Professor Huang, the considerable amount of FDI in China may reflect the weakness, rather than the strength, of the Chinese market. As he explained: 'China's low labor - and land - costs do not automatically motivate a Hong Kong firm to invest in China; instead, they motivate a Hong Kong firm (or any other firm) to do more business with China, as opposed to doing more business with, say, Mexico. China's low labor costs tell us something about the location of a labor-intensive production facility, but not about who owns it' (Ibid, p. 57). Professor Huang therefore credited the superior regulatory and legal treatments of foreign-invested enterprises as an important motivation for private entrepreneurs in China to seek out FDI from its neighbors (Ibid, p. 90). His thesis also illuminates why a substantial amount of investment was derived from businesses in Hong Kong and Taiwan as well as those owned by the Chinese diaspora. After all, if local firms have to reach out for FDI, they are more likely to turn to firms in the so-called Greater China.

In sum, the drastically lower production costs, the country's enormous market, its inefficient economic system and the preferential treatment of foreign investors have all helped to attract FDI in China. Because these factors more than compensate for the country's weak intellectual property protection, FDI in China increased substantially despite limited intellectual property protection in the country. China therefore is not an exception to the causal relationship between intellectual property protection and FDI, but an ideal case study to illustrate the ambiguity of this relationship and the complex interactions between the many location advantages that affect private investment decisions. After all, as Keith Maskus pointed out, if stronger intellectual property protection always led to more FDI, 'recent FDI flows to developing economies would have gone largely to sub-Saharan Africa and Eastern Europe . . . [rather than] China, Brazil, and other high-growth, large-market developing economies with weak IPRs' (Maskus, 1998, p. 129).

\section{INTELLECTUAL PROPERTY REFORMS IN CHINA}

'Since 1983, FDI [in China] has grown from less than $\$ 1$ billion a year to more than $\$ 60$ billion, and it is projected to soon reach $\$ 100$ billion annually' (Navarro, 2007, p. 13). Today, China is one of the world's largest recipients of FDI with capital inflows of about $\$ 50$ billion, behind the United States and the United Kingdom (Chow, 2007, p. 198). Such an influx of FDI not only provides China with the foreign capital needed for economic modernization, but also results in technology transfer, job creation, 


\section{THE CHINA EXCEPTION}

development of human capital and generation of tax revenues (Sherwood, 1990, pp. 191199). Although economists have pleaded for caution in considering the benefits of FDI to recipient countries (Maskus, 1998, p. 146), there is no denial that the influx of foreign capital has contributed to China's recent rise to its status as an emerging economic superpower.

As pointed out earlier, strong intellectual property protection is not always needed for attracting FDI. In fact, stronger protection may reduce investment by encouraging investors to conduct arm's-length transactions by licensing their products. Such protection would also reduce the net gains in economic welfare from increased FDI by incurring significant costs, such as administrative and enforcement costs, adjustment costs due to labor displacement, social costs associated with monopoly pricing, higher imitation and innovation costs and potential costs resulting from the abuse of intellectual property rights (Maskus, Dougherty and Mertha, 2005, pp. 302-306). Stronger intellectual property protection therefore would drain the country's scarce governmental resources, render cutting-edge foreign technologies inaccessible and stifle the development of local industries (Giunta and Shang, 1993, p. 331; Yu, 2000, pp. 189-190). Given the significant costs of strengthening intellectual property protection, Chinese policy makers and commentators understandably were worried that stronger protection would slow down the country's economic progress and therefore would make it difficult for the country to catch up with its Western developed neighbors.

Indeed, as Rod Falvey, Neil Foster and David Greenaway have shown recently, although intellectual property protection promotes innovation in high-income countries and technology flows in low-income ones, middle-income countries may suffer from offsetting losses due to the reduced scope of imitation (Falvey, Foster and Greenaway, 2006). Likewise, as the U.K.-based Commission on Intellectual Property Rights cautioned, 'rapid [economic] growth is more often associated with weaker IP protection. In technologically advanced developing countries, there is some evidence that IP protection becomes important at a stage of development, but that stage is not until a country is well into the category of upper middle income developing countries' (Commission on Intellectual Property Rights, 2003, p. 22).

If the costs of strong intellectual property protection are not enough, the costs of introducing an inappropriate intellectual property system can be quite high for less developed countries. Although overprotection of intellectual property rights harms both developed and less developed countries, it usually harms less developed countries more than it would harm their developed counterparts. Many less developed countries lack the economic strengths and established correction mechanisms to overcome problems created by an unbalanced system ( $\mathrm{Yu}, 2006$, pp. 382-383; Yu, 2007, p. 890). As the Commission noted, "if anything, the costs of getting the IP system "wrong" in a developing country are likely to be far higher than in developed countries. Most developed countries have sophisticated systems of competition regulation to ensure that abuses of any monopoly rights cannot unduly affect the public interest' (Commission on Intellectual Property Rights, 2003, p. 4). Even if stronger intellectual property protection is beneficial to less developed countries in the long run, they may lack the needed wealth, 


\section{THE CHINA EXCEPTION}

infrastructure and technological base to take advantage of the opportunities created by the system in the short run.

In sum, all of these potential negative impacts of stronger intellectual property protection lead one to wonder why China introduced reforms to offer stronger intellectual property protection at all. After all, both theories and actual practice have suggested that China would have limited net economic benefits from stronger intellectual property protection during the first decade of the reopening of the Chinese market to foreign trade. Acknowledging the Chinese leaders' lack of focus on these net benefits in the early development of the modern Chinese intellectual property system, this chapter traces the intellectual property reforms to both external pressure and internal push.

\section{External Pressure}

Shortly after China reopened its market to foreign trade in the late 1970s, China and the United States signed the Agreement on Trade Relations Between the United States of America and the People's Republic of China, which, among other things, called for reciprocal protection of copyrights, patents and trademarks owned by the nationals of the other party. Pursuant to this agreement, China became a member of the World Intellectual Property Organization (WIPO). It also promulgated a new trademark law in 1982 and a new patent law in 1984 and joined the Paris Convention in 1985. Notwithstanding these new developments, China afforded authors and inventors very limited protection, due to the leaders' concern about establishing new private property interests in a socialist economic system, their belief that strong intellectual property protection is inappropriate for a less developed country like China and their inexperience with Western forms of intellectual property protection (Alford, 1995, pp. 66, 70; Mertha, 2005 , pp. 84-86). While the new laws granted individuals rights in their marks and inventions, these statutes included many limits that rendered the original grants largely insignificant.

Concerned about the lack of intellectual property protection in China, copyright in particular, U.S. businesses lobbied their government heavily for stronger pressure on China. In the late 1980s and early 1990s, the U.S. government repeatedly threatened China with a series of economic sanctions, trade wars, non-renewal of most-favorednation status and opposition to China's entry into the WTO (Yu, 2000, pp. 140-151). Such threats eventually led to the issuance or signing of two memoranda of understanding in 1989 and 1992, an 'agreement' regarding intellectual property rights in 1995 (which appeared in the form of an 'exchange of letters' with an attached action plan) and an 'accord' reiterating China's commitment to strengthening intellectual property protection in 1996.

Although the seldom-mentioned 1989 memorandum of understanding reassured the United States that China would strengthen its protection for computer software, the 1992 memorandum was the 'first full bilateral IPR agreement' between China and the United States (Massey, 2006, p. 235). In retrospect, the 1992 memorandum was effective in revamping China's intellectual property system. Pursuant to that document, China acceded to the Berne Convention and ratified the Geneva Convention. China also 
amended its 1990 Copyright Law, issued new implementing regulations and adopted a new unfair competition law that provided trade secret protection.

Likewise, the 1995 Agreement was effective in helping China create an institutional infrastructure conducive to protecting and enforcing rights created under this new intellectual property regime. The Agreement introduced the State Council Working Conference on Intellectual Property Rights, which was later replaced by the State Intellectual Property Office, as well as the Enforcement Task Forces (Yu, 2000, p. 152). To protect CDs, laser discs and CD-ROMs, the agreement established a unique copyright verification system, proposing to punish by administrative and judicial means any manufacturer of audiovisual products who failed to comply with the identifier requirement. The agreement also called for title registration with the National Copyright Administration and local copyright authorities of foreign audiovisual products and computer software in $\mathrm{CD}-\mathrm{ROM}$ format. In addition, the agreement required customs offices to intensify border protection for all imports and exports of CDs, laser discs, CDROMS and trademarked goods. The agreement further stipulated that relevant authorities would conduct training and education on intellectual property protection throughout China. Finally, the agreement provided that the Working Conference would develop a transparent legal system while compiling and publishing guidelines regarding application and protection in various areas of intellectual property law.

Notwithstanding these two agreements, piracy remained rampant in China in the mid-1990s, and the United States was estimated to have lost $\$ 2$ billion of revenues annually due to copyright piracy (Faison, 1998). To make things worse, the ineffectiveness of the coercive tactics used by the United States Trade Representative (USTR) has become apparent to not just Chinese negotiators and seasoned commentators, but also the U.S. industries and the American public. Although the two countries reached another 'accord' in 1996, that document clearly revealed the limitation of the coercive approach. The document included neither significant new terms nor terms that improved market access of American products; instead, it merely reaffirmed China's commitment to protect intellectual property rights made under the intellectual property agreement signed the year before (Yu, 2001, p. 14).

As industry support decreased, the Clinton administration abandoned its strongarm tactics shortly after the 1996 negotiations (Yu, 2003, p. 365). Although the United States continued to exert pressure on China during the negotiation of China's accession to the WTO and undertook frequent consultations with Chinese officials, the United States has yet to revive its coercive approach - partly because of the approach's limitations and partly because of its impracticality after China's WTO membership. Under the WTO, countries are prohibited from taking retaliatory measures before they have exhausted all of the actions permissible under the rules (World Trade Organization, 1999). Except in areas that are outside the scope of the TRIPS Agreement, China's WTO membership has greatly constrained the United States's ability to exert external pressure on China in the intellectual property area. To make up for the lack of external pressure, U.S. businesses now exert pressure from within the country-through persuasion, business pressure and alliances with local stakeholders and authorities. 
In February 2005, U.S. policy makers and trade groups again urged the administration to file a formal complaint against China with the WTO Dispute Settlement Body concerning inadequate intellectual property protection ( $\mathrm{Yu}, 2006, \mathrm{p} .923)$. A few months later, the United States, in conjunction with Japan and Switzerland, invoked article 63(3) of the TRIPS Agreement to formally request 'clarifications regarding specific cases of IPR enforcement that China has identified for the years 2001 through 2004, and other relevant cases' (Allgeier, 2005). In April 2007, the United States finally requested consultations with China concerning its failure to protect and enforce intellectual property rights in pursuance to the TRIPS Agreement. As of this writing, the United States, however, has yet to request the establishment of a WTO dispute settlement panel. If the United States did so, and if China were found to have violated the TRIPS Agreement, external pressure again might play an important role in unleashing and accelerating intellectual property reforms in China.

\section{Internal Push}

\section{Alignment with the National Modernization Goals}

While researchers have explored extensively the relationship between intellectual property protection and economic development, they rarely examine the rhetorical effects of the claim that stronger intellectual property protection will promote economic development. The lack of such an examination is understandable considering the difficulty in quantifying and assessing rhetorical effects. Nevertheless, rhetoric is needed to persuade the populace to accept a new government policy, and may also provide the direction and psychological incentives needed for promoting economic development.

To some extent, the rhetorical significance of the claim that stronger intellectual property protection will promote economic development is similar to the significance of the claim that intellectual property is property. Despite the uneasy analogy of intellectual property to real property, intellectual property rights holders have widely used the rhetoric of private property to push for stronger protection. ${ }^{3}$ Meanwhile, foreign rights holders and governments have also used the economic development rationale to entice foreign leaders and policy makers to ratchet up intellectual property protection and, more specifically, to establish the TRIPS Agreement within the WTO. As Daniel Gervais recounted, developed countries and the lobbies that pushed for stronger intellectual property protection believed that 'TRIPS was a difficult but essential measure to jumpstart global economic development', while less developed countries 'were told to overlook the distasteful aspects of introducing or increasing intellectual property protection and enforcement in exchange for longer-term economic health' (Gervais, 2007, p. 43). Similarly, Edmund Kitch argued that less developed countries agreed to stronger intellectual property protection during the TRIPS negotiations because they found such protection in their self-interests, although the negotiation records and the reactions of less developed countries offered very limited support for Professor Kitch's account (Kitch, 1994, p. 138; Maskus, 1998). ${ }^{4}$

While the rhetorical linkage of intellectual property to economic development is important to induce less developed countries to offer stronger protection, it is particularly 
important to a country like China, which has placed heavy emphasis on symbols and political movements and was emerging from autarky and diplomatic isolation. Since the reopening of the Chinese market to foreign trade in the late 1970s, Deng Xiaoping and other reformist leaders advocated a pragmatic 'economics in command' approach to replace Mao Zedong's 'politics in command'. Seeing economic wealth as the foundation of China's power, the reformist leadership believed 'whether China could have a rightful place in the world of nations depended on China's domestic economic development' (Zheng, 1999, p. 17). These leaders therefore vigorously pushed for the Four Modernizations to develop China's world-class strengths in agriculture, industry, science and technology and national defense. They also established Special Economic Zones to transform socio-economic conditions in coastal areas and renewed diplomatic and commercial ties with the United States, Japan and other Western developed countries. The 1979 U.S.-China trade agreement was a product of this urgent push for greater internationalization.

While economic development was easily justified by the severe need for reforms following the Cultural Revolution, the death of Mao Zedong and the subsequent arrest of the infamous Gang of Four, the justification for intellectual property reforms remained elusive. Indeed, when China reopened its market to foreign trade in the late 1970s, both the Chinese leaders and the populace considered intellectual property an alien concept transplanted from Western soil. As William Alford pointed out in his seminal work, To

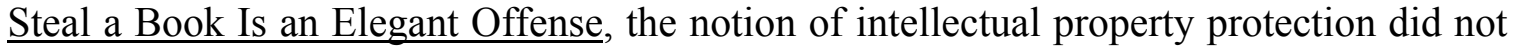
take root in China despite earlier attempts to transplant the concept onto the country through bilateral commercial treaties at the turn of the twentieth century and intellectual property reforms during the Republican era (Alford, 1995, pp. 36-55). Even if those reforms introduced the concept to the Chinese populace, the numerous class struggles, mass movements and the Cultural Revolution that rejected ownership of private property virtually eliminated from public consciousness the concept of intellectual property $(\mathrm{Yu}$, 2001, pp. 21-22).

Thus, when this concept was reintroduced in the 1980s, the justification for such a concept was badly needed. In his well-cited chapter concerning justifications for intellectual property protection, William Fisher identified four possible justificationsutility, labor, personality and social planning (Fisher, 2001, pp. 169-173). For a society that was making a transition from a command economy, rather than today's socialist market economy, the first and second justifications were easily deemed unsuitable. Indeed, early Chinese intellectual property laws were filled with compromises that resulted in what commentators called 'socialist legality with Chinese characteristics' (Alford, 1995, p. 70). While the Chinese leadership was anxious to create a stimulus for inventions and to rehabilitate scientists, inventors and academics to make up for the time lost to the Cultural Revolution, (Ibid, p. 65) the leaders remained gravely concerned about the impact of new intellectual property rights on the country's socialist economic system.

The third justification, which was based on personality theories, was attractive to the Chinese, because it sat well with Communist ideology and the Soviet notion of nonproperty-based protection of authorship. Recent research by Mira Sundara Rajan, for 
example, has shown that the Russian Copyright Act of 1928 granted limited recognition to the authors' property interests by 'plac[ing] them within the broader context of a nonproperty theory of authorship' (Sundara Rajan, 2005, p. 333). As a 1938 commentary on the Russian Law noted, the Soviet author's right 'has the objective of protecting to the maximum the personal and property interests of the author, coupled with the assurance of the widest distribution of the product of literature, science and the arts among the broad masses of the toilers' (Ibid, p. 334). Nevertheless, the personality justification-in particular, its emphasis on moral rights - was inconsistent with foreign demands for stronger intellectual property protection, which reflected the interests of and the more utilitarian approach embraced by Western rights holders.

The most suitable justification was therefore what Professor Fisher described as 'social planning', which ranges from the development of the economy to the nurturing of an attractive intellectual culture (Fisher, 2001, pp. 192-193; Netanel, 1996, p. 288). As he explained, '[t]his approach is similar to utilitarianism in its teleological orientation, but dissimilar in its willingness to deploy visions of a desirable society richer than the conceptions of "social welfare" deployed by utilitarians' (Fisher, 2001, p. 172). This justification therefore fit well with China in the early 1980s, and economic modernization provided the needed 'social planning' justification for a new intellectual property system. Since then, intellectual property reforms have been linked to the country's rapid economic development and have benefited from the push for continuous economic reforms.

Politically, backing the newly-established intellectual property system with rhetoric that was consistent with the national modernization goals was very important. As David Zweig suggested, directions from the leadership and rhetoric that conveys these directions are critical to a country that is undergoing 'a fundamental change in [its] international orientation' (Zweig, 2002, p. 27). Because the Chinese leaders were inexperienced with intellectual property protection and had to constantly struggle with unfamiliar concepts and models introduced during the transitional period, the alignment of intellectual property reforms with the national modernization goals also allowed leaders to defend intellectual property reforms on more familiar terms.

In addition, because reformist leaders were constantly challenged by their more conservative counterparts, who were uncomfortable with the country's rapid socioeconomic changes and the social ills brought about by these changes, the rhetoric allowed the reformist leaders to deflate criticisms of their kowtowing to foreign interests, especially in times of considerable external pressure from the United States. Instead, the leaders could highlight the economic benefits of stronger intellectual property protection and justify intellectual property reforms as an important leapfrogging tool to enable China to catch up with its more advanced trading partners. The reformist leadership could also tie the reforms to the growing nationalist sentiments that longed for China's regaining its rightful place following centuries of humiliation and semi-colonial rule (Hsü, 2000, pp. 660-661).

Moreover, the fact that stronger intellectual property protection is unnecessary for attracting FDI does not mean that an increase in protection would not result in more 
economic development. In fact, it would, at least in certain parts of the country or in selected industrial sectors. The more profits a firm can obtain, the more likely it is to expand its business, and the greater is its investment in or trade with the country. This is particularly true with respect to a country that has a strong imitative capacity and an enormous growing market. Indeed, stronger intellectual property protection may also provide to foreign investors important signals of a favorable investment climate (Alford, 1995, p. 68; Maskus, 1998, pp. 137-138). As Claudio Frischtak noted, a country's overall investment climate is often more influential on FDI decisions than the strength of intellectual property protection it offers (Frischtak, 1993, pp. 99-100). Likewise, Carsten Fink and Keith Maskus stated that '[a] poor country hoping to attract inward FDI would be better advised to improve its overall investment climate and business infrastructure than to strengthen its patent regime sharply, an action that would have little effect on its own' (Fink and Maskus, 2005, p. 7). Thus, stronger intellectual property protection might result in more foreign investment from existing investors as well as those who otherwise would not invest in the country. While serious questions remain concerning whether stronger protection would result in net gains in economic welfare within the country, and whether such protection, on balance, would benefit the country, those questions do not negate the fact that stronger intellectual property protection would induce some economic development in the country.

In sum, even though stronger intellectual property protection is unnecessary for promoting economic development, the claim that stronger intellectual property protection would promote economic development provided the needed internal push for intellectual property reforms in the first decade and a half following the reopening of the Chinese market to foreign trade. In retrospect, that claim, to some extent, was similar to what psychologists have termed a 'self-fulfilling prophecy'. Although people might not be able to prove conclusively whether stronger intellectual property protection would lead to greater economic development, they would accept a higher level of protection if they believed such a link existed. This higher level of protection, in turn, would result in greater economic development in certain parts of the country and in selected industrial sectors. As more local stakeholders stood to benefit from stronger protection, they would lobby for even stronger protection. Eventually, the belief in the benefits of stronger intellectual property protection would result in more economic development, regardless of whether the link existed in the first place. And the cycle would repeat itself.

\section{Development of Local Stakeholders}

China experienced major economic setbacks after Tiananmen in 1989 and the subsequent turbulent bilateral relationship with the United States and other Western countries. Fortunately, its economy quickly recovered following Deng Xiaoping's famous 'tour' of southern China in 1992. In March 1993, the National People's Congress incorporated into the Chinese Constitution the concept of the socialist market economy, which contrasted powerfully with a command or centrally-planned economy. ${ }^{5}$ Four years later, the private sector was designated an important component of the changing economy, and 'red capitalists' were invited to join the Chinese Communist Party at the Sixteenth Party Congress in 2001 (Prestowitz, 2005, p. 27). Today, article 13 of the Constitution stipulates that '[c]itizens' lawful private property is inviolable', and booming real estate 
markets appear in many major Chinese cities. Most recently, the National People's Congress enacted a much-anticipated, yet controversial law to offer explicit protection to private property (Kahn, 2007).

Accompanying this rapid economic development and growth was the emergence of local stakeholders who stood to benefit from stronger intellectual property protection. Consider, for example, the software industry, which has experienced tremendous growth since the mid-1990s. By 1997, the value of the software market had doubled from RMB 6.8 billion in 1995 to RMB 12.6 billion (Xue and Zheng, 1999, p. 8). The Chinese government also has been active in developing the local software industry, establishing bases in Liaoning, Hunan, Shandong and Sichuan Provinces and in Beijing, Shanghai and Zhuhai districts (Ibid, p. 9).

Today, the number of private software companies has greatly increased. Although state-owned enterprises once dominated the Chinese economy, a large number of employees of these enterprises are now entering the private sector-or, in the Chinese parlance, 'plunging into the sea' (xiàhăi). As the late Zheng Chengsi and Xue Hong, two leading commentators on Chinese intellectual property law, observed:

In recent years ... many software engineers resigned from state enterprises or research institutes, taking software products (finished or unfinished) created during the course of employment with them, and joined private software companies or established their own companies. These private companies immediately produced and marketed the software products, and became competitors of state software enterprises (Xue and Zheng, 2002, pp. 104-105).

In the late 1990s, intellectual property reforms were given a further push by the emerging consciousness of the need to develop a knowledge-based economy. As Lester Thurow noted, ' $[\mathrm{k}]$ nowledge is the new basis for wealth. . . . In the past, when capitalists talked about their wealth, they were talking about their ownership of plant and equipment or natural resources. In the future when capitalists talk about their wealth, they will be talking about their control of knowledge' (Thurow, 1999, p. xiii). Perhaps under the influence of the internet boom in other parts of the world, the phrase 'knowledge economy' suddenly began to appear in major Chinese newspapers, such as The People's Daily and Guangming Daily. Government officials used the phrase frequently in their presentations (Xue and Zheng, 1999, p. 7), while Chinese businesses quickly adopted words like 'e-commerce' and 'e-business' to enhance public image and stock market value (Xue and Zheng, 2002, p. xl).

Although the internet bust a few years later slowed online developments throughout the world, the drive for the development of a knowledge-based economy in China continued, and the Chinese internet population grew exponentially. In October 1997, there were only 299000 computers connected to the internet and 620000 internet users (Yu, 2003, p. 371). Based on the most recent survey by the China Internet Network Information Center (CNNIC), there are now 58.4 million computers connected to the internet and 137 million internet users, second only to the United States (China Internet Network Information Center, 2007, p. 5). 
As the use of the internet and new communications technologies continues to increase, Chinese policy makers have paid greater attention to issues concerning intellectual property rights in the digital environment. For example, the 2001 copyright law amendments addressed for the first time online copyright issues. In May 2006, the State Council promulgated the Regulations on the Protection of the Right of Communication Through Information Network. Most recently, China acceded to the WIPO Copyright Treaty and the WIPO Performances and Phonograms Treaty. These developments make a lot of sense. Greater certainty over the scope of rights protected on the internet is important to both local and foreign content providers and will greatly facilitate electronic commerce and broadband deployment.

The biggest push for intellectual property reforms in the 1990s was China's accession to the WTO. As China prepared to join the international trading body, it undertook a complete overhaul of its intellectual property system, amending its copyright, patent and trademark laws. In addition, it introduced a large number of implementing regulations and administrative measures, such as those concerning the registration of computer software and those on the protection of topographies of integrated circuits. To help courts interpret these new laws and regulations, the Supreme People's Court also issued a number of judicial interpretations (Sun, 2004, pp. 66-67).

In November 2001, the WTO members finally approved the proposal to admit China to the international trading body during the Fourth Ministerial Conference in Doha, Qatar. After fifteen years of exhaustive negotiations, China formally became the 143rd member of the WTO on 11 December 2001. Although the accession process was complicated and involved many inextricable factors, it would not be far-fetched to argue that China might still remain outside the WTO had it not strengthened its protection of intellectual property rights (Yu, 2003, p. 372). Indeed, some commentators considered the WTO membership a major impetus for China's recent improvements in intellectual property protection. As Professors Zheng and Xue explained:

In general, China's entry to the WTO significantly influenced the speed and scope of the development of the Chinese IP law system. It is interesting to note that IP rights reforms kept pace with Chinese WTO negotiations. When the negotiations encountered obstacles, the IP rights reform slowed down; when the negotiations reached agreements to promote the accession process, the IP rights reform accelerated noticeably. Since China has become a member of the WTO, Chinese IP law reform has also peaked (Xue and Zheng, 2002, p. xxxix).

To some extent, the economic benefits and reputational gains that were associated with China's accession to the WTO far exceeded the socio-economic costs incurred by increased intellectual property protection. By linking the two issues together, the Chinese began to understand that the stakes for the lack of intellectual property protection extended beyond the intellectual property arena, covering almost every other area that implicates international trade, including agriculture, banking, electronics, insurance, professional services, securities, telecommunications and textiles ( $\mathrm{Yu}, 2003$, p. 371). While they might not be excited about introducing stronger intellectual property protection, they certainly were reluctant to give up WTO-related trade benefits that were linked to such protection. 
Moreover, the moderate costs of stronger protection required by the TRIPS Agreement were incomparable to the high costs of other reforms required by the WTO accession. If the leaders and the Chinese public were willing to accept the costs of these other reforms, it was natural for them to accept the costs of TRIPS-related reforms. In fact, one could make a strong claim that China could easily recoup its losses in the intellectual property area by obtaining gains in such other trade areas as agriculture or textiles. Even critics of the overall economic benefits of China's accession had a tough time responding to the strong nationalistic sentiments that considered the WTO accession an important means for China to regain its past glory, not to mention the general excitement, rejuvenation and other psychological benefits brought about by the accession.

Nevertheless, one needs to be cautious about how much one attributes the recent intellectual property reforms to China's WTO accession. Although commentators and policy makers have widely credited the recent changes in the Chinese intellectual property system to the WTO accession, it is important not to overlook the many internal developments within the country, including the Chinese leaders' changing attitude toward the rule of law, the emergence of private property rights and local stakeholders, the increasing concerns about ambiguities over relationships in state-owned enterprises and the government leaders' active push for modernization (Yu, 2006, p. 908). While the WTO accession may be important, China's guóqíng, or national conditions, continues to play a very important role in shaping intellectual property reforms in China.

\section{Increasing Shift toward an Export-Driven Economy}

Today, China is 'the world's fourth largest economy and the third largest trading nation' (Bergsten, Gill, Lardy and Mitchell, 2006, p. 3). Its imports 'tripled from \$225 billion in 2000 to $\$ 600$ billion in 2005 ', and the country 'accounted for about 12 percent of the growth of global trade', an impressive jump from only 4 per cent in 2000 (Ibid, p. 73). Its factories 'make 70 percent of the world's toys, 60 percent of its bicycles, half its shoes, and one-third of its luggage' (Shenkar, 2005, p. 2). China also 'builds half of the world's microwave ovens, one-third of its television sets and air conditioners, a quarter of its washers, and one-fifth of its refrigerators' (Ibid, p. 3). As the Chinese economy becomes increasingly driven by exports to other countries, intellectual property protection will become even more important than it was a decade ago. As Daniel Chow explained:

[g]lobal competitiveness in the modern age is directly linked to the level of technology in goods and services. Studies indicate that the higher the level of technology involved in goods and services, the higher the growth rate of exports. . . In the 1990s, China began to build a trade surplus with many nations based upon its low manufacturing costs. While China has been able to dominate in lowtechnology/labor-intensive industries, China realizes that to continue its growth in exports, it must move up the ladder into more technology-intensive goods and services. To do so, China must acquire access to advanced technology (Chow, 2006, p. 206).

Indeed, 'China, like most nations, encourages exports because export sales contribute to a favorable trade balance and can earn United States dollars or other forms of hard currency' (Ibid, p. 214). While Chinese companies were content to serve as 
original equipment manufacturers (OEM) for foreign firms a decade ago, they have now moved into high-end technology markets, such as those for cars and regional jets, while seeking to maintain their competitive edge over low-cost products (Ibid, pp. 207-208; Shenkar, 2005, pp. 161-162). Thus, some commentators and pundits suggested that China's export-driven economic growth is likely to lead to greater future confrontations with the United States. As Peter Navarro observed, '[a]ny complete understanding of the Coming China Wars must begin with this observation: China's hyper-rate of economic growth is export driven; and the ability of the Chinese to conquer one export market after another, often in blitzkrieg fashion, derives from their ability to set the so-called China Price' (Navarro, 2007, p. 2).

Consider, for example, trademark protection, which is particularly important to an export-driven economy. The usual criticism of strong trademark protection in an emerging economy is that such protection would force local consumers to pay a premium for well-known foreign brands in exchange for no or very limited benefits. This is particularly true when local consumers are brand-conscious or when their purchase decisions are distorted by their obsession with social status, which they seek to gain by buying or owning more expensive foreign products. Because most of the branded products are made in China, local consumers are often asked to pay a higher price even though the quality of the products is no different from that of products made by local brand owners.

Moreover, by intentionally not offering trademark protection, countries may be able to take a free ride on the investment of foreign trademark holders, by earning profits as if they were selling genuine goods that bear the infringing marks. As foreign brand owners continue to advertise and promote their products, the local copycats would also benefit from the goodwill of the original products without incurring any advertising expenses. Such a competitive strategy, however, is ill-advised, especially for a country that has now become one of the world's largest exporters. As Professor Kitch explained, that strategy 'will result in a parasitical business that will always be dependent on the willingness of the targeted countries to tolerate the infringing imports . . . [and that] will never have an established market position that can lay a foundation for the development of an internationally competitive business' (Kitch, 1994, p. 168).

To be certain, local firms can ensure the marketability of their products in foreign countries by using non-infringing trademarks in foreign markets. Indeed, global firms have used that strategy to avoid infringement in selected markets. Nevertheless, such a strategy is costly, because it will not allow for the economies of scale commonly found in global production. That strategy also makes it difficult for local firms to learn how to establish market position by experimenting in the local market with brand development and trademark portfolio management. To some extent, one can see the local market as a 'playground' for Chinese export businesses to acquire the needed skills to set up internationally competitive businesses.

A case in point is the leading Chinese personal computer manufacturer, Lenovo (Liánxiăng). When the company sought to expand business overseas a few years ago, it found out that its English name 'Legend' had already been registered and used as a 
trademark or trade name in many foreign countries. To avoid potential infringement and to ensure that it could become an official sponsor of the 2008 Beijing Olympics, it had no choice but to develop the new 'Lenovo' mark, which combined the first two letters of the 'Legend' mark with the word 'novo' (Ling, 2006, pp. 334-335). Interestingly, the 'Lenovo' mark has now become famous as a result of the worldwide media coverage of its purchase of IBM's personal computers division.

Lenovo, however, is not the only one. Compared to a decade ago, a number of Chinese companies have now achieved prominence in the international market, with their trademarks being recognized as well-known outside China (Sull with Wang, 2005). Examples of these famous local brands include Galanz (for microwave ovens), Haier (for household appliances), Huawei Technologies (for telecommunications equipment), Konka (for televisions) and TCL (for televisions). As China increases its exports of goods branded with globally recognized local trademarks, the importance of intellectual property protection to the country's future economic development cannot be ignored.

From the standpoint of internal economic development in China, trademark protection is even more beneficial than the protection afforded by other forms of intellectual property. The development of globally recognized trademarks requires neither considerable technological expertise nor initial heavy capital investment. Although the global market has been dominated by brands developed by major corporations in developed countries, less developed countries and smaller enterprises have their fair share of famous trademarks that are recognized throughout the world, especially in the fields of beer and liquor production-Bacardi (for Bermuda rum), Corona (for Mexican beer) and Tsingtao (for Chinese beer) easily come to mind (MacLaughlin, Richards and Kenny, 1988, p. 104). ${ }^{6}$ In fact, according to Interbrand, 'Bacardi is the world's 75th most valuable global brand, and with a valuation in excess of \$3 billion, is worth comfortably more than the GDP of the country which produces it' (Anholt, 2005, p. 60).

From the standpoint of consumer welfare and economic self-sufficiency, it is also helpful to encourage local companies to catch up and compete with famous Western brands by developing more attractive products and better brand positioning (Yu, 2006, p. 996). Instead, this brand building strategy 'fits [well] with the government's strategy of consolidating strategic industries . . . to create national champions that can hold their own in global markets and ... to restore its imperial glory' (Shenkar, 2005, p. 158). Compared to foreign firms, local firms thus far have been very successful in the Chinese market. In this dynamic, yet immature market, 'consumers are still experimenting, and brands come and go with great speed' (Chee with West, 2004, p. 30; Yan, 2004, p. 95). As a result, local firms have the opportunity to attain market position and develop the next promising brands.

The ability of local firms to improve consumer loyalty and establish market position has been further enhanced by the failure of foreign firms to understand or adjust to the local market conditions. Studies, for example, have 'estimated that less than 10 percent of Chinese consumers have the level of disposable income that can afford to buy Western products' (Chee with West, 2004, p. 31). Yet many foreign businesses ignore 
this financial reality and insist on focusing on the high-end market, perhaps due to benefits from economies of scope and scale in global production, or to the firms' reluctance to lower the quality, and often the international reputation, of their products.

A case in point is the microwave market, which Galanz has overtaken recently. '[I]n 1993 only 1 per cent of Chinese consumers had microwaves. Consumption grewbut not in the pattern expected. By early 2000, nearly 90 per cent of the market was in cheaper models, with the Chinese company Galanz dominating' (Ibid). Similarly, although Whirlpool and Kelon were competitors for the manufacture of washing machines, the local manufacturer quickly won the race (Huang, 2005, pp. 193-194). Today, '[a]fter losing more than $\$ 100$ million and shutting down most of its factories, Whirlpool ... manufactures washing-machines for Guangdong Kelon'-a scenario that Whirlpool certainly did not foresee when it began its investment in China (Anholt, 2005, p. 64).

As China continues to increase exports and develop products under globally recognized trademarks, especially after the much-anticipated push around the 2008 Beijing Olympics (and again during the 2010 World Expo in Shanghai), the existence of effective intellectual property protection is likely to be of paramount importance. Significant improvement in trademark protection is therefore likely to be more important to China than similar improvement in the protection of other forms of intellectual property. In fact, the improved ability of Chinese businesses to develop globally famous brands may ultimately hold the key to converting those Chinese who are sceptical of intellectual property protection to global missionaries for greater intellectual property reforms.

\section{CONCLUSION}

Commentators have considered China the proverbial exception to the causal relationship between the strength of intellectual property protection and the amount of FDI attracted to the country. However, this chapter has shown that this causal relationship is more ambiguous than experts have claimed and China illustrates rather well the ambiguity of this relationship. While stronger intellectual property protection may be unnecessary for attracting FDI, this chapter has documented an undeniably intertwined relationship between intellectual property protection and economic development in China. Intellectual property protection can therefore be seen broadly as an integral and essential part of a complex innovation system that serves as a catalyst for economic development. If a country is to be further developed economically, the implementation of an effective and robust intellectual property system that is tailored to local needs and conditions is likely to be significant.

Today, piracy and counterfeiting problems remain widespread in China, and rights holders continue to be frustrated by the lack of enforcement of intellectual property rights in the country. However, at some point in the near future, China may reach a crossover point at which it will find it in its self-interest to offer stronger intellectual property protection. Indeed, similar transformations occurred in Japan in the 1970s and in Hong Kong, Singapore, South Korea and Taiwan in the 1980s - and even in Germany 
and the United States many decades ago (Assafa, 1996, p. 120; Kingston, 2005, p. 658). It is only a matter of time before China joins its more developed neighbors in championing the cause for stronger intellectual property protection.

\section{NOTES}

1. For discussions of the United States's potential WTO complaint against China before the WTO Dispute Settlement Body concerning a lack of general enforcement of intellectual property rights, see Yu, 2005; Yu, 2006, 923-946.

2. Some commentators have added a third type of FDI, distribution FDI, referring to 'investment in local sales offices, distribution networks, and services facilities' (Kennedy, 2003, p. 79 n.5).

3. For discussions or critiques of the use of the private property rhetoric to expand intellectual property protection, see Bell, 2003, pp. 273-277; Netanel, 2003, p. 22; Stallman, 2005; Sterk, 2005, p. 420.

4. For my earlier discussion of this self-interest narrative, see Yu, 2006b, pp. 376379.

5. The amended Article 15 of the 1982 Chinese Constitution now reads: 'The State has put into practice a socialist market economy. The State strengthens formulating economic laws, improves macro adjustment and control and forbids according to law any units or individuals from interfering with the social economic order.'

6. For a detailed discussion of emerging brands in less developed countries, see Anholt, 2005, pp. 43-77.

\section{REFERENCES}

Abbott, Frederick M. (2005), 'Toward a New Era of Objective Assessment in the Field of TRIPS and Variable Geometry for the Preservation of Multilateralism', Journal of International Economic Law, 8(1), 77-100.

Alford, William P. (1995), To Steal a Book Is an Elegant Offense: Intellectual Property Law in Chinese Civilization, Stanford, Calif.: Stanford University Press.

Allgeier, Peter F. (2005), Letter to HE Mr Sun Zhenyu, Ambassador, Permanent Mission of the People's Republic of China to the World Trade Organization, http://www.ustr.gov/assets/Document_Library/Reports_Publications/2005/asset_upload_f ile115_8232.pdf.

Anholt, Simon (2005), Brand New Justice: How Branding Places and Products Can Help the Developing World, 2nd edn, Oxford: Butterworth-Heinemann.

Assafa, Endeshaw (1996), Intellectual Property Policy for Non-industrial Countries, Brookfield, Mass.: Dartmouth. 
Bell, Tom W. (2003), 'Authors' Welfare: Copyright as a Statutory Mechanism for Redistributing Rights', Brooklyn Law Review, 69(1), 229-280.

Bergsten, C. Fred, Bates Gill, Nicholas R. Lardy and Derek Mitchell (eds) (2006), China: The Balance Sheet: What the World Needs to Know Now About the Emerging Superpower, New York: Public Affairs.

Chee, Harold with Chris West (2004), Myths about Doing Business in China, New York: Palgrave Macmillan.

China Internet Network Information Center (2007), 19th Statistical Survey Report on the Internet Development in China, Beijing: China Internet Network Information Center.

Chow, Daniel C. K. (2006), 'Why China Does Not Take Commercial Piracy Seriously', Ohio Northern University Law Review, 32(2), 203-225.

Chow, Daniel C. K. (2007), 'The Role of Intellectual Property in Promoting International Trade and Foreign Direct Investment', in Peter K. Yu (ed.), Intellectual Property and Information Wealth: Issues and Practices in the Digital Age, Westport, Conn.: Praeger Publishers, 4, pp. 187-200.

Commission on Intellectual Property Rights (2003), Integrating Intellectual Property Rights and Development Policy: Report of the Commission on Intellectual Property Rights, London: Commission on Intellectual Property Rights, http://www.iprcommission.org/papers/pdfs/final_report/CIPRfullfinal.pdf.

Dunning, John H. (1981), International Production and the Multinational Enterprise, London: George Allen \& Unwin.

Faison, Seth (1998), 'China Turns Blind Eye to Pirated Disks', New York Times, 28 March, p. D1.

Falvey, Rod, Neil Foster and David Greenaway (2006), 'Intellectual Property Rights and Economic Growth', Review of Development Economics, 10(4), 700-719.

Fink, Carsten and Keith E. Maskus (2005), 'Why We Study Intellectual Property Rights and What We Have Learned', in Carsten Fink and Keith E. Maskus (eds), Intellectual Property and Development: Lessons from Recent Economic Research, Oxford: Oxford University Press, pp. 1-15.

Fisher, William (2001), 'Theories of Intellectual Property', in Stephen R. Munzer (ed.), New Essays in the Legal and Political Theory of Property, Cambridge: Cambridge University Press, pp. 168-199.

Frischtak, Claudio R. (1993), 'Harmonization Versus Differentiation in Intellectual Property Rights Regime', in Mitchel B. Wallerstein, Mary Ellen Mogee and Roberta A. Schoen (eds), Global Dimensions of Intellectual Property Rights in Science and Technology, Washington, D.C.: National Academy Press, pp. 89-106. 
Gervais, Daniel J. (2007), 'The TRIPS Agreement and the Doha Round: History and Impact on Economic Development', in Peter K. Yu (ed.), Intellectual Property and Information Wealth: Issues and Practices in the Digital Age, Westport, Conn.: Praeger Publishers, 4, pp. 23-72.

Giunta, Tara Kalagher and Lily H. Shang (1993), 'Ownership of Information in a Global Economy', George Washington Journal of International Law and Economics, 27(2-3), $327-358$.

Heald, Paul J. (2003), 'Mowing the Playing Field: Addressing Information Distortion and Asymmetry in the TRIPS Game', Minnesota Law Review, 88(2), 249-314.

Hsü, Immanuel C.Y. (2000), The Rise of Modern China, 6th edn, Oxford: Oxford University Press.

Huang, Yasheng (2005), Selling China: Foreign Direct Investment During the Reform Era, Cambridge: Cambridge University Press.

International Intellectual Property Alliance (2007), 2007 Special 301: People's Republic of China-Amended, Washington, D.C.: International Intellectual Property Alliance.

Kahn, Joseph (2007), 'China Approves Property Law, Strengthening Its Middle Class', New York Times, 16 March, p. A1.

Kennedy, Kevin C. (2003), 'A WTO Agreement on Investment: A Solution in Search of a Problem?', University of Pennsylvania Journal of International Economic Law, 24(1), $77-188$.

Kingston, William (2005), 'An Agenda for Radical Intellectual Property Reform' in Keith E. Maskus and Jerome H. Reichman (eds), International Public Goods and Transfer of Technology Under a Globalized Intellectual Property Regime, Cambridge: Cambridge University Press, pp. 653-661.

Kitch, Edmund W. (1994), 'The Patent Policy of Developing Countries', UCLA Pacific Basin Law Journal, 13(1), 166-178.

Ling, Zhijun (Martha Avery (trans)) (2006), The Lenovo Affair: The Growth of China's Computer Giant and Its Takeover of IBM-PC, Singapore: John Wiley \& Sons.

MacLaughlin, Janet H., Timothy J. Richards and Leigh A. Kenny (1988), 'The Economic Significance of Piracy', in R. Michael Gadbaw and Timothy J. Richards (eds), Intellectual Property Rights: Global Consensus, Global Conflict?, Boulder, Colo.: Westview Press, pp. 89-108.

Mansfield, Edwin (1994), Intellectual Property Protection, Foreign Direct Investment and Technology Transfer, Washington, D.C.: World Bank. 
Maskus, Keith E. (1998), 'The Role of Intellectual Property Rights in Encouraging Foreign Direct Investment and Technology Transfer', Duke Journal of Comparative and International Law, 9(1), 109-161.

Maskus, Keith E. (2000), Intellectual Property Rights in the Global Economy, Washington, D.C.: Institute for International Economics.

Maskus, Keith E., Sean M. Dougherty and Andrew Mertha (2005), 'Intellectual Property Rights and Economic Development in China', in Carsten Fink and Keith E. Maskus (eds), Intellectual Property and Development: Lessons from Recent Economic Research, Oxford: Oxford University Press, pp. 295-331.

Massey, Joseph A. (2006), 'The Emperor Is Far Away: China's Enforcement of Intellectual Property Rights Protection, 1986-2006', Chicago Journal of International Law, 7(1), 231-237.

Mertha, Andrew C. (2005), The Politics of Piracy: Intellectual Property in Contemporary China, Ithaca, N.Y.: Cornell University Press.

Navarro, Peter (2007), The Coming China Wars: Where They Will Be Fought and How They Can Be Won, Upper Saddle River, N.J.: Financial Times Press.

Netanel, Neil Weinstock (1996), 'Copyright and a Democratic Civil Society', $\underline{\text { Yale Law }}$ Journal, 106(2), 283-387.

Netanel, Neil Weinstock (2003), 'Impose a Noncommercial Use Levy to Allow Free Peer-to-Peer File Sharing', Harvard Journal of Law and Technology, 17(1), 1-84.

Prestowitz, Clyde (2005), Three Billion New Capitalists: The Great Shift of Wealth and Power to the East, New York: Basic Books.

Primo Braga, Carlos Alberto and Carsten Fink (1998), 'The Relationship Between Intellectual Property Rights and Foreign Direct Investment', Duke Journal of Comparative and International Law, 9(1), 163-187.

Schlender, Brent, Warren Buffett and Bill Gates (1998), 'The Bill \& Warren Show', Fortune, 20 July, pp. 48-52.

Shenkar, Oded (2005), The Chinese Century: The Rising Chinese Economy and Its Impact on the Global Economy, the Balance of Power, and Your Job, Upper Saddle River, N.J.: Wharton School Publishing.

Sherwood, Robert M. (1990), Intellectual Property and Economic Development, Boulder, Colo.: Westview Press.

Stallman, Richard M. (2005), 'Did You Say "Intellectual Property"? It's a Seductive Mirage', http://www.fsf.org/licensing/essays/not-ipr.xhtml. 
Sterk, Stewart E. (2005), 'Intellectualizing Property: The Tenuous Connections Between Land and Copyright', Washington University Law Quarterly, 83(2), 417-470.

Sull, Donald N. with Yong Wang (2005), Made in China: What Western Managers Can Learn from Trailblazing Chinese Entrepreneurs, Boston, Mass.: Harvard Business School Press.

Sun, Catherine (2004), China Intellectual Property for Foreign Business, Hong Kong: LexisNexis.

Sundara Rajan, Mira T. (2005), 'Copyright and Free Speech in Transition: The Russian Experience', in Jonathan Griffiths and Uma Suthersanen (eds), Copyright and Free Speech: Comparative and International Analyses, Oxford: Oxford University Press, pp. 315-355.

Tackaberry, Paul (1998), 'Intellectual Property Risks in China: Their Effect on Foreign Investment and Technology Transfer', Journal of Asian Business, 14(4), 1-38.

Thurow, Lester C. (1999), Building Wealth: The New Rules for the Individuals, Companies, and Nations in a Knowledge-Based Economy, New York: HarperBusiness.

World Trade Organization (1999), Panel Report: United States-Sections 301-310 of the Trade Act of 1974, WT/DS152/R.

Xue, Hong and Zheng Chengsi (1999), Software Protection in China: A Complete Guide, Hong Kong: Sweet \& Maxwell Asia.

Xue, Hong and Zheng Chengsi (2002), Chinese Intellectual Property Law in the 21st Century, Hong Kong: Sweet \& Maxwell Asia.

Yan, Rick (2004), 'Short-Term Results: The Litmus Test for Success in China', in Harvard Business Review: Doing Business in China, Boston, Mass.: Harvard Business School Press, pp. 79-140.

Yu, Peter K. (2000), 'From Pirates to Partners: Protecting Intellectual Property in China in the Twenty-First Century', American University Law Review, 50(1) 131-243.

Yu, Peter K. (2001), 'Piracy, Prejudice, and Perspectives: An Attempt to Use Shakespeare to Reconfigure the U.S.-China Intellectual Property Debate', Boston University International Law Journal, 19(1), 1-87.

Yu, Peter K. (2003), 'The Copyright Divide', Cardozo Law Review, 25(1), 331-445.

Yu, Peter K. (2005), 'Still Dissatisfied After All These Years: Intellectual Property, PostWTO China, and the Avoidable Cycle of Futility', Georgia Journal of International and Comparative Law, 34(1), 143-158. 
Yu, Peter K. (2006), 'From Pirates to Partners (Episode II): Protecting Intellectual Property in Post-WTO China', American University Law Review, 55(4), 901-1000.

Yu, Peter K. (2006b), 'TRIPS and Its Discontents', Marquette Intellectual Property Law Review, 10(2), 369-410.

Yu, Peter K. (2007), 'The International Enclosure Movement', Indiana Law Journal, 82(4), 827-907.

Yu, Peter K., Gordon G. Chang, Jerome A. Cohen, Elizabeth C. Economy, Sharon K. Hom and Adam Qi Li (2003), 'Symposium, China and the WTO: Progress, Perils, and Prospects', Columbia Journal of Asian Law, 17(1), 1-29.

Zheng, Yongnian (1999), Discovering Chinese Nationalism in China: Modernization, Identity, and International Relations, Cambridge: Cambridge University Press.

Zweig, David (2002), Internationalizing China: Domestic Interests and Global Linkages, Ithaca, N.Y.: Cornell University Press. 